\title{
Clinical-evolutive, diagnostic and treatmental particularities in traumatic diaphragmatic hernia in children. Clinical case presentation and literature review
}

\author{
${ }^{1}$ PMSI Institute of Mother and Child National Scientific-Practical Center of Pediatric Surgery \\ "Natalia Gheorghiu», Chisinau, Republic of Moldova \\ ${ }^{2}$ Nicolae Testemițanu State University of Medicine and Pharmacy, Chisinau, Republic of Moldova
}

Diaphragmatic-traumatic hernia represents an entity in the child. Frequency reduced, delayed clinical manifestations, nonspecific symptomatology determines multiple diagnostic difficulties, which increases the risk of developing severe complications.

The authors present the case of a 4-year-old child with late manifestations of traumatic diaphragmatic hernia. The certainty diagnosis was established at thoracic CT with dynamic contrast in angiographic regime. The child underwent surgical treatment.

The authors concluding that the primary repair with the application of nonabsorbable sutures and the concomitant use of the acellular pericardial mold for consolidation is an effective option in the surgical reconstruction of traumatic diaphragmatic defects in children.

The authors declare no conflicts of interests.

Key words: children, traumatic diaphragmatic hernia, complications, surgical treatment.

Клініко-еволюційні, діагностичні та лікувальні особливості травматичної діафрагмальної грижі у дітей. Клінічний випадок та огляд літератури

\section{S. Babuci, ${ }^{1,2}$, V. Eremia ${ }^{2}$, V. Petrovici ${ }^{1}$}

${ }_{1}^{1}$ Державна медико-санітарна установа Інститут матері та дитини, Національний науково-практичний центр дитячої хірургії "Академік Наталья Георгіу», м. Кишинів, Республіка Молдова

${ }^{2}$ Державний університет медицини та фармакології імені Николая Тестеміцану, м. Кишинів, Республіка Молдова

Діафрагмально-травматична грижа - це дитяче захворювання. Низька частота розвитку, відстрочені клінічні прояви та неспецифічна симптоматика створюють множинні діагностичні труднощі, що підвищує ризик розвитку важких ускладнень.

Автори наводять клінічний випадок пізніх проявів травматичної діафрагмальної грижі у 4-річної дитини. Достовірний діагноз був установлений за допомогою комп'ютерної томографії грудної клітки з динамічним контрастним ангіографічним режимом. Дитина пройшла хірургічне лікування. Автори роблять висновок, що первинне відновлення із використанням неабсорбованих швів у поєднанні із залученням безклітинної перикардіальної форми для ущільнення є ефективним варіантом хірургічного відновлення травматичних діафрагмальних дефектів у дітей.

Автори заявляють про відсутність конфлікту інтересів.

Ключові слова: діти, травматична діафрагмальна грижа, ускладнення, хірургічне лікування.

\footnotetext{
Клинико-эволюционные, диагностические и лечебные особенности травматической диафрагмальной грыжи у детей. Клинический случай и обзор литературы

S. Babuci, ${ }^{1,2}$, V. Eremia ${ }^{2}$, V. Petrovici ${ }^{1}$

${ }^{1}$ Государственное медико-санитарное учреждение Институт матери и ребенка, Национальный научно-практический центр детской хирургии «Академик Наталья Георгиу», г. Кишинев, Республика Молдова

${ }^{2}$ Государственный университет медицины и фрармакологии имени Николая Тестемицану, г. Кишинев, Республика Молдова

Диафрагмально-травматическая грыжа представляет собой детское заболевание. Низкая частота развития, отсроченные клинические проявления и неспецифическая симптоматика создают множественные диагностические трудности, что повышает риск развития тяжелых осложнений.

Авторы приводят клинический случай поздних проявлений травматической диафрагмальной грыжи у 4-летнего ребенка. Достоверный диагноз был установлен при КТ грудной клетки с динамическим контрастным ангиографическим режимом. Ребенок прошел хирургическое лечение.
} 


\section{Клінічний випадок}

Авторы приходят к выводу, что первичное восстановление с применением неабсорбируемых швов и сопутствующего использования бесклеточной перикардиальной формы для уплотнения является эффективным вариантом хирургического восстановления травматических диафрагмальных дефектов у детей.

Авторы заявляют об отсутствии конфликта интересов.

Ключевые слова: дети, травматическая диафрагмальная грыжа, осложнения, хирургическое лечение.

\section{Introduction}

Traumatic diaphragmatic hernia (HDT) is a rare disease in children. The incidence of HDT ranging from $0.08 \%$ to $8 \%$ is reported in the literature, with mortality rates ranging from $16.6 \%$ to $33.3 \%$ [3]. The reduced frequency, the non-specificity of the symptoms, the clinical evolution with associated lesions causes multiple diagnostic difficulties in $50-70 \%$ of cases, a high index of suspicion being necessary [8]. Late manifestation of traumatic lesions of the diaphragm is studied more in adults than in children [4]. In this context we present the following clinical case.

\section{Case report}

Patient S., 4 years old, was transferred on 24.01.2020 to our institution from a district hospital where she was hospitalized on 19.01.2020, being suspected clinically-radiologically a paraesophageal hiatal hernia, but was not excluded and a destructive pulmonary process with pulmonary abscess formation (fig. 1). At the time of hospitalization, the patient had unexplained violent abdominal pain in the epigastric region and in the left hypochondria, fever $\left(38.5^{\circ} \mathrm{C}\right)$, constipation, the symptomatology being present for 4 days.

From anamnesis: a month ago the child was treated in the hospital for a respiratory infection. Upon discharge, the therapeutic effect was confirmed radiologically, intrathoracic formations were not detected. Two weeks before the onset of the new symptoms, the baby fell, hitting the chair, the accident being overlooked by the mother. On 19.01.2020, during the game, the child became suddenly agitated, the listed symptoms appeared, which over the years worsened significantly.

The clinical examination revealed the serious general condition, conditioned by the presence of signs of exicosis, stable hemodynamics. Pale skin, cyanosis of the nasal lip triangle, tachypnea and tachycardia. Auscultative, on the left side, breathing did not occur, except for the apical area. Palpation - painful abdomen all over the surface, predominantly in the epigastric region and in the left hypochondriac region. Laboratory examination revealed anemia (erythrocytes $-3.5 \times 10^{6} / \mathrm{ul}, \mathrm{Hb}-105 \mathrm{~g} / \mathrm{l}$ and neutrophil leukocytosis $\left.10.9 \times 10^{9} / 1\right)$.

The thoracic and abdominal radiography, performed by emergency in the clinic, showed the trans diaphragmatic positioning of the intestinal handles in the left hemi thorax, the diaphragmatic hernia having large dimensions than before (fig. 2).

The diagnostic of certainty was established with the help of thoracic CT with dynamic contrast in angiographic regime, which confirmed the subtotal prolapse of the large

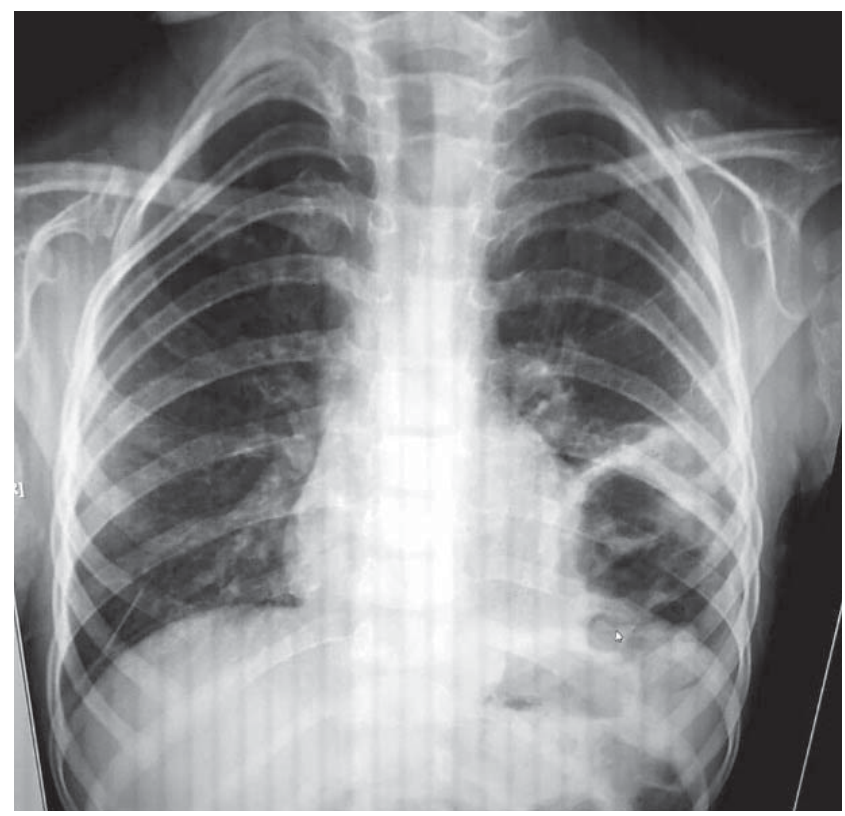

Fig. 1. Preoperative chest x-ray. Explanations in the text

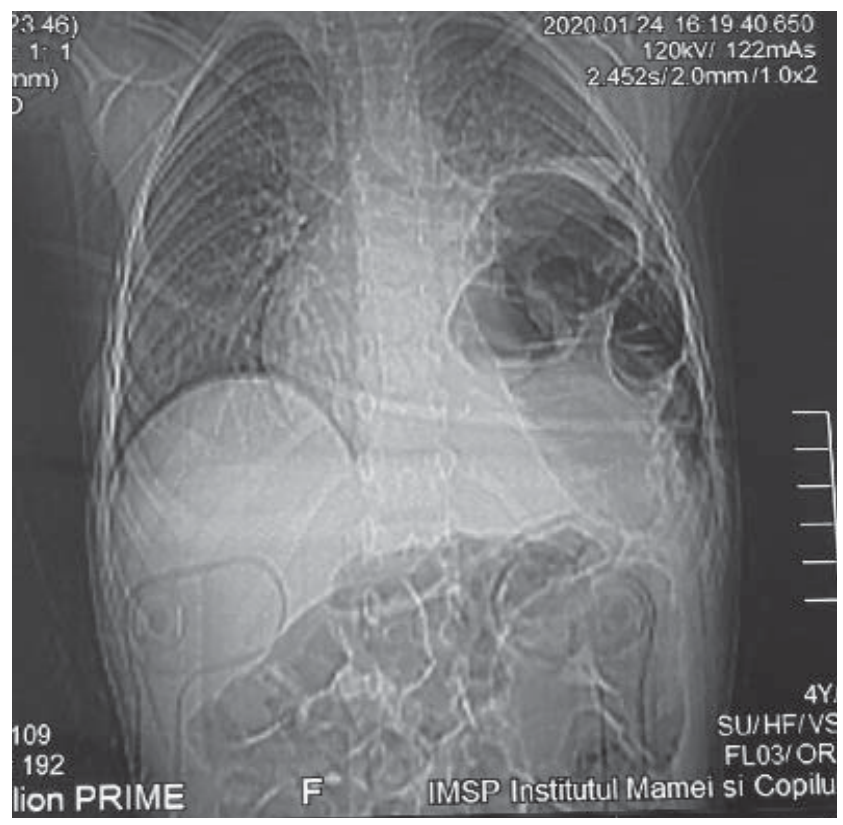

Fig. 2. Patient S., 4 years. Chest x-ray at the time of hospitalization (more than 4 days after disease onset). Visualization of bowel prolapse in the left hemithorax with compression of the lower lobe of the left lung is visualized 


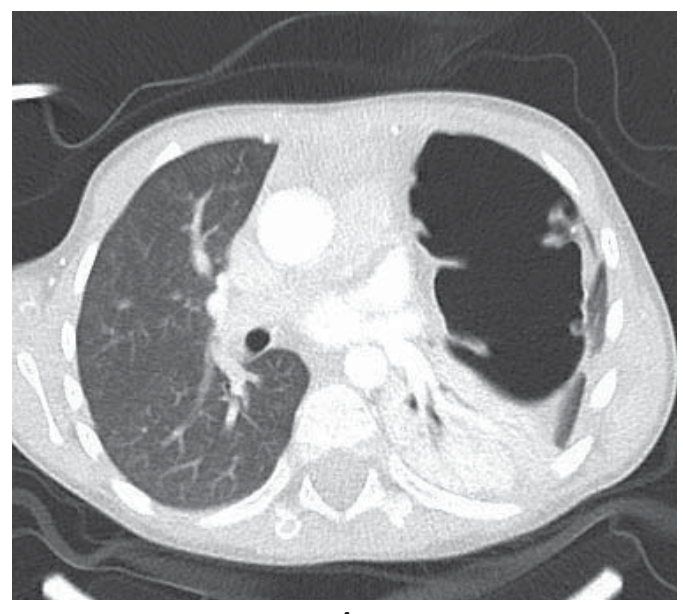

A

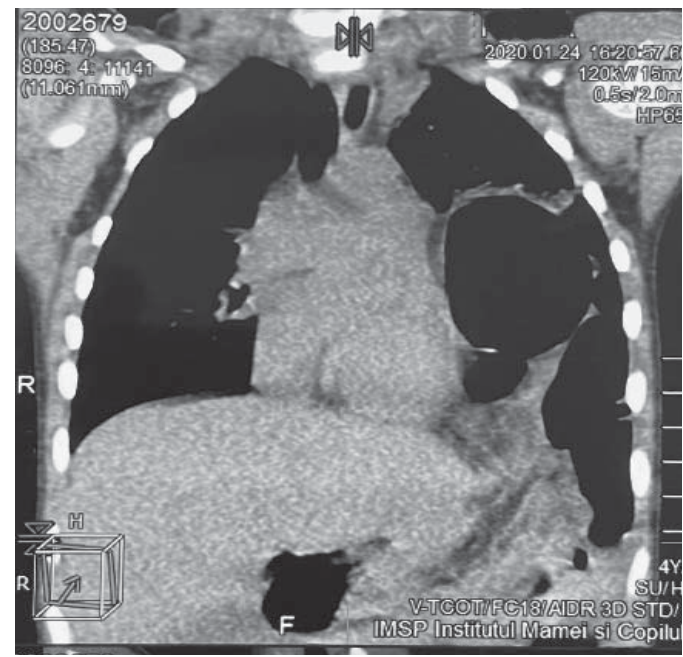

$D$
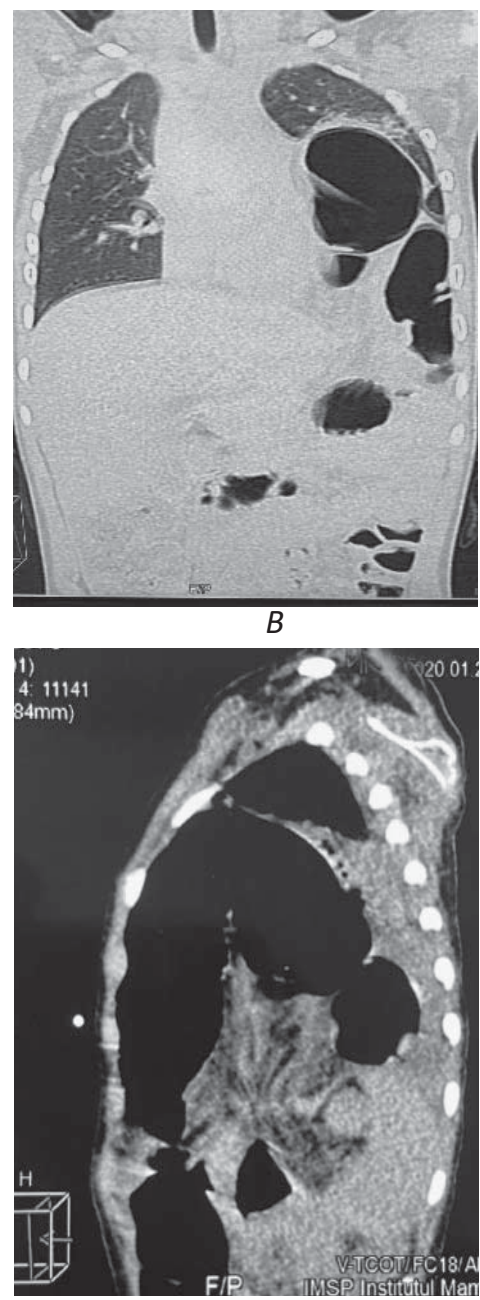

E
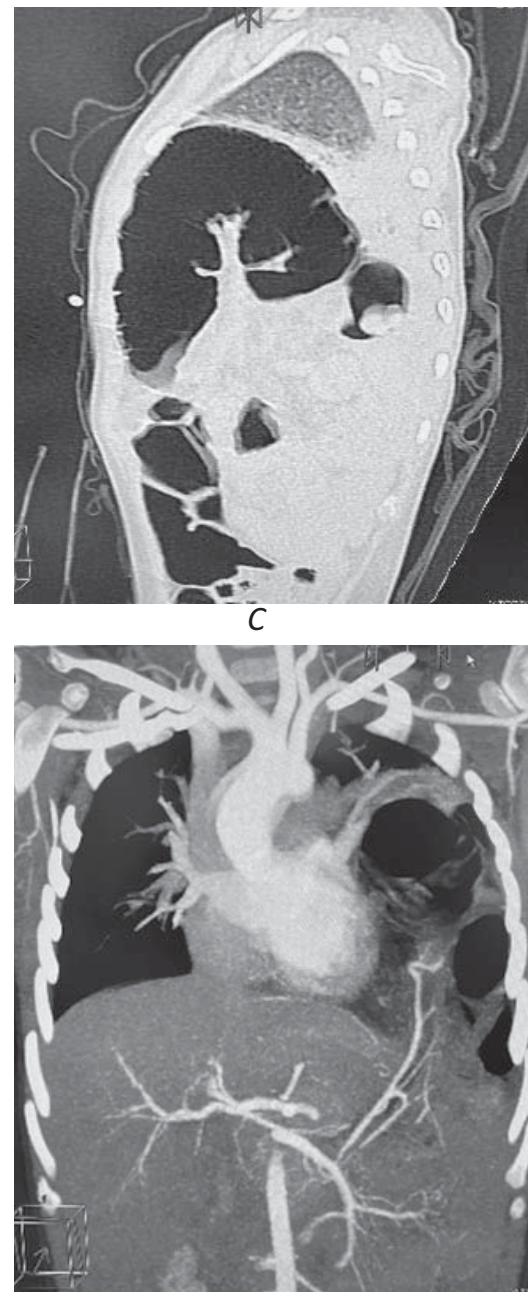

F

Fig. 3. Patient S., 4 years. Preoperative thoracic and abdominal CT. Subtotal prolapse of the small and large intestine handles in the cavity of the left hemithorax is visualized by a defect of the left hemidiaphragm with total atelectasis of the lower lobe of the left lung. Pleural effusion

and small intestine handles by a defect of $2 \mathrm{~cm}$ diameter centrally located at the level of the left hem diaphragm. The total atelectasis of the lower lobe of the left lung was determined with fluid accumulation in the left pleural cavity, stomach and spleen located orthotopically (fig. 3).

After a 2-hour preoperative preparation, surgery was performed, performing a left subcostal laparatomy. Intraoperatively, a defect of the left hemidiaphragm was detected (Fig. 4) at the fusion level of the anterior part of the tendon and the muscular part. Through this defect the intrathoracic hernia the omentum, colon and small intestine handles. A portion of the omentum adheres intimately to the edges of the diaphragmatic defect. After the reduction of the eviscerated organs in the pleural cavity it was found that the segment of herniated omentum had severe and trophic inflammatory changes, which was resected. Cyanotic herniated bowels, on the surface multiple petechiae. The mesou with significant changes of vascular stasis and petechial foci. After debridement of the defect area, the integrity of the diaphragm was restored with non-absorbable interrupted sutures. For the purpose of consolidation, a biodegradable acellular biological graft fragment of equine pericardium (Bioteck Heart) was applied. The pleural cavity was drained by microtoracotomy with tubular drainage, and the abdominal cavity with a glove blade drainage. The operation was completed with the restoration of the anatomical structure of the anterior abdominal wall.

Histologically, in the tissues taken from the margins of the diaphragmatic defect, a lympho-plasmocytic inflammatory process with macrophage elements, more frequent in the vicinity of the cellulose adipose tissue islets, and the adhesive fibrillary cellulose tissues (with predominantly non-connective tissue, predominating in the adipose tissue) was revealed (Fig. 5A). In some areas of the tissue plastic area, outbreaks of young unformed connective tissue were attested which, at times, mimic the mature granulation tissue, with the accentuation of proliferative fibrovascular processes. The density of unformed fibrillar tissue was variable, in some areas with 


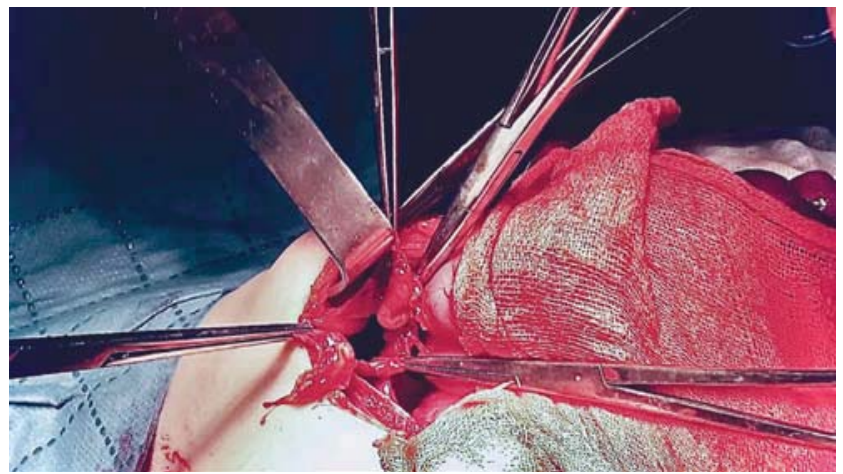

Fig. 4. The intraoperative aspect of the diaphragmatic defect

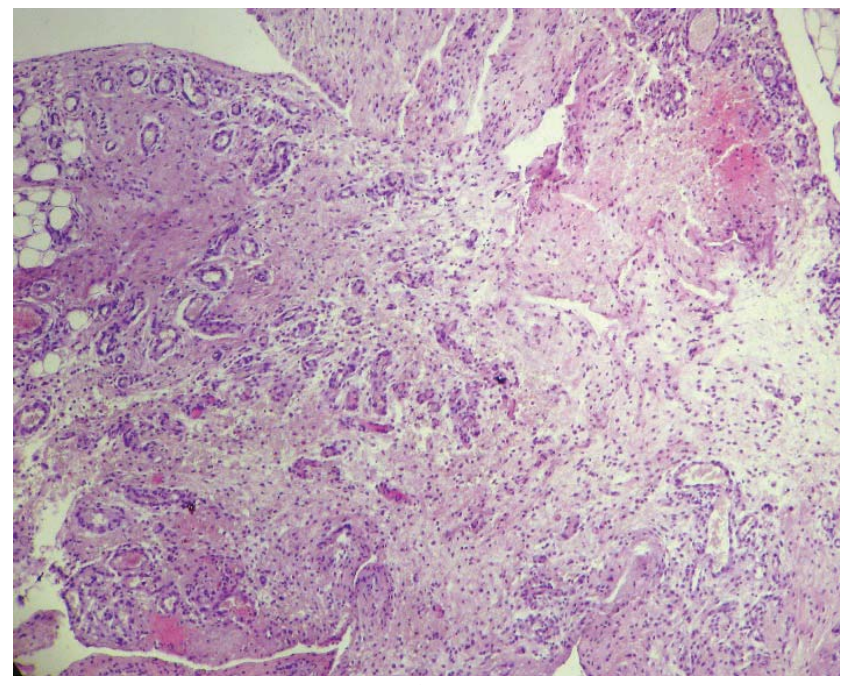

A

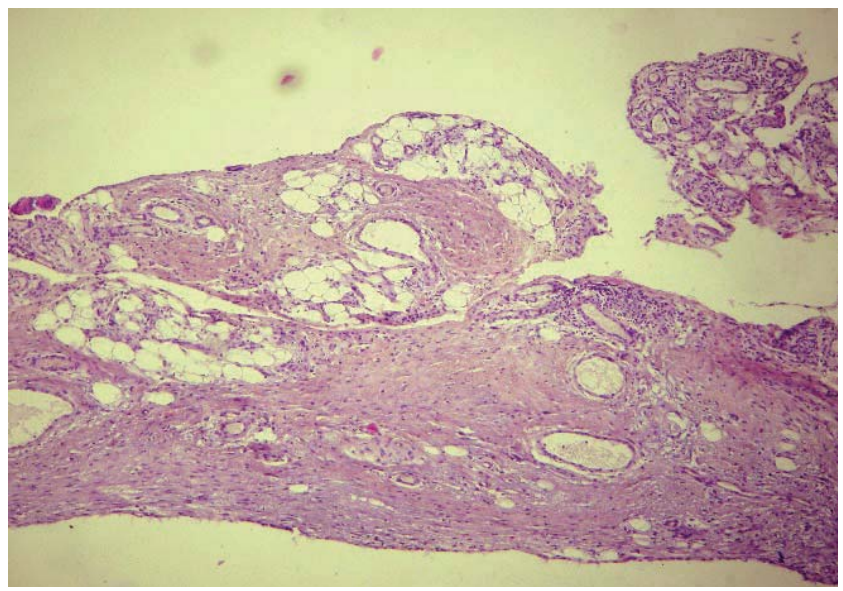

$B$

Fig. 5. Morphopathological aspects of the marginal tissues around the diaphragmatic defect: A - fibrillar-conjunctival plast vascularized with nerve bundles (1), the presence of the non-formed adhesive process (2) and lymphoplasmocitary inflammatory (3). $\times 25$. Color. H\&E; B - fibrillar connective tissue with proliferative fibrovascular features. $\times 75$. Color. $H \& E$

ordered fibrillar appearance (Fig. 5B). In part, the process was circumscribed by adhesive fibroblastic processes. In the non-formed adhesions, marked by mature granulations, there was an increase of the proliferative processes of vascular and fibroblastic, compared with the
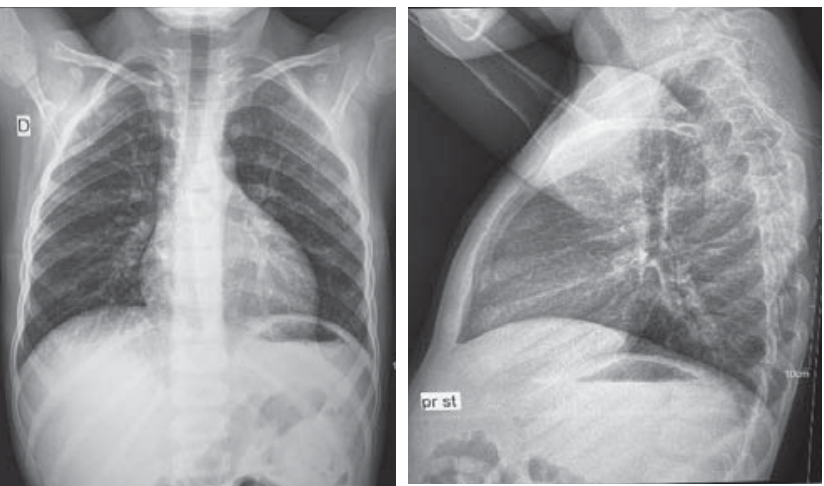

Fig. 6. Patient S., 4 years. Chest radiograph in 2 projections of the 9th postoperative day. It determines the usual lung volume, the intensified lung pattern, the reaction of the interlobar pleura on the left, without pneumonic opacity. Contour of the left hemidiaphragm clear, pleural sinuses free

fibrillar component, frequently associated with the presence of lymphocytes and granulocytes from discrete to moderate. In some areas, excessive vascularization and fibroblastic proliferative-cellular processes with reduced conjunctival fibrillar component have been observed, which mimic angiomatous processes. The lack of hemosiderosis indicates at lesions of tissue contusion and disjunction of the hemidiaphragmous resident tissue.

Under the protection of a conservative antibacterial treatment and hydroelectrolyte rebalancing, the patient was recovered without complications, being discharged at the 10th postoperative day in a good general condition. Radiologically, on the 9th day after the intervention, a pulmonary drawing without pneumonic opacities was visualized, the contour of the left hemidiaphragm being well highlighted (fig. 6).

\section{Discussions}

The first description of the traumatic lesions of the diaphragm belongs to Sennertus (1541), and the first described case (in 1579) of diaphragmatic rupture, diagnosed at autopsy, to Ambroise Pare. Herniation of the stomach through the diaphragm following trauma was mentioned by Ambroise Pare in 1580. In 1853, H.I. Bowditch published the first case of HDT diagnosed with death, establishing five diagnostic criteria. In 1886, Riolfi performed the first successful intervention of a penetrating diaphragm injury, and Walker, in 1899, successfully reduced a diaphragmatic hernia and repaired the diaphragm [7].

Traumatic lesions of the diaphragm are caused by thoraco-abdominal traumatic injuries $(75 \%)$ or penetrating (25\%), the rate of severe injuries being $44-94 \%$. In children, HDTs are more commonly located (90\%) on the left side [9]. HDTs are considered to be the consequence of the sudden increase of the pleuroperitoneal pressure gradient and occur in the weak areas along the 
embryonic fusion points. Migration of intraperitoneal organs into the pleural space, with compression of the lung and displacement of mediastinum, compromises cardiovascular and respiratory functions. Thus, dysfunction of a hemi diaphragm leads to a reduction of lung function by $25-50 \%$ [7].

Three evolutionary phases of the rupture of the diaphragm are described: 1 ) the acute phase - at the time of the traumatic injury of the diaphragm; 2) phase two - transient herniation of the viscera; 3 ) third phase - development of complications such as strangulation and the appearance of symptoms of intestinal obstruction, pulmonary compression, mortality rate increasing up to $20-80 \%$ [4].

Clinical symptoms in HDT are dominated by respiratory distress (86\%), abdominal pain (17\%), shortness of breath on the affected side (73\%), some patients experiencing chest pain, vomiting.

It is considered that only $25-50 \%$ of traumatic lesions of the diaphragm are diagnosed by initial chest radiography [4]. According to reports, this method allows the detection of pathognomonic or suggestive signs in $70-85 \%$ of cases, while $\mathrm{CT}$ of the chest and abdomen confirms the diagnosis, with a sensitivity of up to $82 \%$ and a specificity of $87 \%$ [8]. Radiological signs suggestive of HDT include: elevated hemidiaphragm, distorted and obscured diaphragmatic margins, presence of intestinal shadows or air levels above the diaphragm, pleural collection, pulmonary collapse, and contralateral displacement of mediastinum [1].

HDT treatment is surgical, by abdominal or thoracic approach, and involves the replacement of the herniated organs under the diaphragm, drainage of the pleural cavity and repair of the diaphragmatic defect. Surgical repair is necessary even for minor defects, which will not heal spontaneously, and the thoraco-abdominal pressure gradient favors the enlargement of the defect with herniation of the abdominal organs [3]. Reconstruction of the diaphragmatic defect can be performed with nonabsorbable sutures interrupted in one or two layers [6]. In some cases, the use of synthetic or biological meshes can be used in the reconstruction of post-traumatic diaphragmatic defects [2].

Some authors consider that laparoscopy is a safe procedure in resolving cases of traumatic diaphragmatic hernias in patients with stable hemodynamics [5]. In the treatment of HDT, it is also possible to use video-assisted thoraco- scopic surgery for both diagnostic and treatment purposes, careful selection of patients being essential for the success of this method [10].

Thus, in young children HDT is a major challenge that can occur as a result of traumas, «insignificant» at first sight, overlooked by parents. These can evolve quietly, the clinical symptomatology developing suddenly after certain periods of time, which requires the collection of a thorough anamnestic history Preoperative diagnosis of HDT in young children is quite difficult, thoracic CT with dynamic contrast in angiographic regime being an effective method in establishing the diagnosis with certainty. The results of the histological examination indicate that the mechanism development of diaphragmatic defect in children may occur as a result of tissue contusion injury and subsequent disruption of the resident hemi diaphragmatic tissue. in the surgical reconstruction of traumatic diaphragmatic defects.

The authors declare no conflicts of interests.

\section{References}

1. El-Yacub AI, Bello UM, Sheshe AA, Naaya HU. (2017). Delayed presentation of posttraumatic diaphragmatic hernia masquerading as recurrent acute asthmatic attack. Case Report. Hindawi Case Rep. Med. Art. ID 5037619. 3 pag. https://doi.org/10.1155/2017/5037619.

2. Hurdle V, Ly K, Yeung JK, Graham AJ, Gelfand GA, Schrag C. (2018). Reconstruction of diaphragmatic defects with human acellular dermal matrix: A case series and literature review. Plastic Surg. Case Studies. 4: 1-5. doi: 10.1177/2513826X17751113.

3. Kishore GS, Gupta V, Doley RP, Kudari A, Kalra N. (2010). Traumatic diaphragmatic hernia: tertiary centre experience. Hernia. 14: 159-64.

4. Kumar KJ, Kumar MG. (2013). Delayed presentation of traumatic diaphragmatic hernia. Indian Pediatrics. 50: 709.

5. Latic F, Delibegovic S, Latic A, Samardzic J, Zerem E. (2010). Laparoscopic repair of traumatic diaphragmatic hernia. Med. Arch. 64(2): 121-2.

6. Lu J, Wang B, Che X, Li X, Qiu G. (2016). Delayed traumatic diaphragmatic hernia: A case-series report and literature review. Medicine (Baltimore). 95(32): e4362.

7. Lundgren J, Mousavie SH, Negahi AR, Varga G, Granehed H. (2017). A review on Traumatic diaphragmatic rupture. Trauma Emerg. Care. 2(5): 1-4. doi: 10.15761/TEC.1000145.

8. Marzona F, Parri N, Nocerino A, Giacalone M, Valentini E. (2019). Traumatic diaphragmatic rupture in pediatric age: review of the literature. Eur. J. Trauma Emerg. Surg. 45(1): 45-58.

9. Okur MH, Uygun I, Arslan MS, Aydogdu B, Turkoglu A. (2014). Traumatic diaphragmatic rupture in children. J. Pediatr. Surg. 49:420-3.

10. Sokolov YuYu, Khaspekov DV, Topilin OG, Shakhin AV, Rassovsky SV, Pachek OA. (2014). Thoracoscopic correction of posttraumatic diaphragmatic hernia in a child with combined injury. Pediatr. Surg. (Rus.). 6: 52-4.

\section{Відомості про авторів:}

Babuci Stanislav Ivanovich - проф., Державний університет медицини та фармації імені Н. Тестеміцану, м. Кишинів, Молдова.

Eremia Victor Vadimovich - Державний університет медицини та фармації імені Н. Тестеміцану, м. Кишинів, Молдова.

Petrovici Vergil Gheorghevich - кандидат наук, Інститут матері та дитини; Національний науково-практичний центр дитячої хірургії «Наталья Георгиу», м. Кичинів, Молдова.

Стаття надійшла до редакції 12.04.2020 р., прийнята до друку 08.06.2020 p. 